\title{
Life quality of patients with inflammatory bowel disease: integrative review
}

\section{Qualidade de vida de pacientes com doença inflamatória intestinal: revisão integrativa}

\section{Calidad de vida de pacientes con enfermedad inflamatoria intestinal: revisión integrativa}

\author{
Rayzza Santos Vasconcelos ${ }^{1}$, Roseanne Montargil Rocha², Evelyn Barbosa Souza1, \\ Verônica Rabelo Santana Amaral ${ }^{3}$
}

\section{ORCID IDS}

Vasconcelos RS (D) https://orcid.org/0000-0001-9276-3731

Rocha RM (iD https://orcid.org/0000-0001-5766-413X

Souza EB (D) https://orcid.org/0000-0002-7933-8789

Amaral VRS (D) https://orcid.org/0000-0003-1657-0254

\section{HOW TO CITE}

Vasconcelos RS; Rocha RM; Souza EB; Amaral VRS. Life quality of patients with inflammatory bowel disease: integrative review. ESTIMA, Braz. J. Enterostomal Ther., 16: e2118. doi: 10.30886/estima.v16.480

\begin{abstract}
Objective: To identify the scientific production about life quality (LQ) of people with inflammatory bowel disease (IBD) in the period from 2012 to 2016. Method: This is an integrative literature review realized in the Scientific Electronic Library Online database (SciELO) in which the articles published freely in Portuguese and/or English published in the last five years and with the descriptors IBD and LQ were used as inclusion criterion. Results: Eight articles were identified and, after partial reading, four were selected, three of which were published in 2015 and one in 2014. The discoveries are in line with other studies that show that vitamin D and ferric carboxymaltose may improve the LQ of patients with IBD. It was also found that women and Crohn's disease predominate among people with IBD, and that LQ is usually negatively affected in these patients, with repeUCssions on their personal and professional relationships. Conclusion: There was a shortage of literature on LQ of people with IBD, mainly in studies conducted in Brazil, since only one clinical study was found.
\end{abstract}

DESCRIPTORS: Stomatherapy; Inflammatory bowel diseases; Life quality.

\footnotetext{
${ }^{1}$ Universidade Estadual de Santa Cruz - Curso de Graduação em Enfermagem - Ilhéus/BA - Brazil.

¿Universidade Estadual de Santa Cruz - Departamento de Ciências da Saúde - Ilhéus/BA - Brazil.

3Universidade Estadual do Sudoeste da Bahia - Mestrado em Ciências da Saúde - Jequié/BA - Brazil.

Corresponding author Rayzza Santos Vasconcelos | Rua Cosme e Damião, 125 - São Caetano | ZIP Code: 45607.030 - Itabuna/BA - Brasil | E-mail: rayzzauesc@gmail.com

Received: May 032017 | Accepted: Mar 192018
} 


\section{RESUMO}

Objetivo: Identificar a produção científica sobre a qualidade de vida (QV) de pessoas com doença inflamatória intestinal (DII) no período de 2012 a 2016. Método: Trata-se de revisão integrativa de literatura realizada na base de dados Scientific Electronic Library Online (SciELO) na qual utilizaram-se, como critério de inclusão, os artigos disponibilizados gratuitamente na íntegra, no idioma português e/ ou inglês, publicados nos últimos cinco anos e com os descritores DIl e QV. Resultados: Foram identificados oito artigos e, após leitura parcial, selecionaram-se quatro, sendo três publicados em 2015 e um em 2014. Os achados vêm ao encontro de outros estudos que mostram que a vitamina D e a carboxymaltose férrica podem melhorar a QV dos pacientes com DII. Verificou-se, também, que o sexo feminino e a doença de Crohn predominam entre as pessoas com DII, e que a QV, geralmente, é afetada de forma negativa nesses pacientes, trazendo repercussões nas suas relações pessoais e profissionais. Conclusão: Foi identificada escassez de literatura sobre QV de pessoas com DII, principalmente em estudos realizados no Brasil, visto que só foi encontrado apenas um estudo clínico.

DESCRITORES: Estomaterapia; Doenças inflamatórias intestinais; Qualidade de vida.

\section{RESUMEN}

Objetivo: Identificar la producción científica sobre la calidad de vida (CV) de personas con enfermedad inflamatoria intestinal (DII) entre el periodo de 2012 a 2016. Método: Se trata de la revisión integrativa de literatura realizada en la base de datos Scientific Electronic Library Online (SciELO) en la cual se utilizaron, como criterio de inclusión, los artículos completos disponibilizados gratuitamente, en el idioma portugués y/o inglés, publicados en los últimos cinco años y con las palabras clave DII y QV. Resultados: Se identificaron ocho artículos y, después de una lectura parcial, se seleccionaron cuatro, tres publicados en 2015 y uno en 2014. Los temas se relacionan a otros estudios que muestran que la vitamina D y la carboxymaltosis férrica puede mejorar la QV de los pacientes con DII. Se verificó, también, que el sexo femenino y la enfermedad de Crohn predominan entre las personas con DII, y que la QV, generalmente es afectada en forma negativa en estos pacientes, trayendo repercusiones en sus relaciones personales y profesionales. Conclusión: Se identificó la escasez de literatura sobre QV de personas con DII, principalmente en estudios realizados en Brasil, ya que solo se encontró un estudio clínico.

DESCRIPTORES: Estomaterapia; Enfermedades inflamatorias intestinales; Calidad de vida.

\section{INTRODUCTION}

Inflammatory bowel disease (IBD) corresponds to a group of autoimmune, chronic diseases that present recurrences and the etiology is not known. This group involves Crohn's disease (CD) and ulcerative colitis (UC), conditions that are characterized by debilitating patients and presenting a dysregulated immune response of the intestinal mucosa ${ }^{1}$.

$\mathrm{CD}$ and $\mathrm{UC}$ are a serious health problem, affecting people of all age groups, especially young people, and clinical forms of seriousness may occur. These diseases cause important repercussions on the life quality (LQ) of the people who have them ${ }^{2}$.

Faced with its chronicity, the person with IBD needs to stay hospitalized several times and use lifelong treatment. The purpose of this treatment is to improve the individual's perception of their health-related LQ(HRLQ), since IBD compromises the physical and psychological domains of their life. Its clinical manifestations are in the intestinal and extraintestinal systemic scope $e^{3,4}$.
$\mathrm{CD}$ has no cure and the drugs used in the treatment only relieve the symptoms and improve the individual's LQ. This disease affects any part of the gastrointestinal tract, however the most affected part is the bowel; the common symptoms are abdominal pain, diarrhea, weight loss and fever, and the three main forms of the disease are inflammatory, fistulous and fibrostenosing ${ }^{5}$.

As in $\mathrm{DC}$, the $\mathrm{UC}$ is of unknown origin and autoimmune in character. It primarily affects the colon and rectum and attend with chronic diarrhea. Even, joint involvement may occur in both the UC and the $\mathrm{DC}^{6}$. It is important to emphasize that there is a high relation between these inflammatory diseases of the colon and the accomplishment of surgery that results in definitive stoma ${ }^{7}$.

With the presence of the stoma, the individual changes its habits and its way of life, leading, in most cases, to the rupture of social and professional relations. It can be said that the stoma together with IBD has repercussions on the well-being and self-esteem of these people, affecting their psychological and social aspects and, consequently, compromising their $\mathrm{LQ}^{8}$. 
According to the literature, $L Q$ is a complex term that addresses subjectivity and is related to various aspects of life'. Precisely because it impairs the performance of activities of daily living and affects the physical, psychological and social dimensions, IBD is considered incapacitating and, consequently, compromises the LQ of these individuals ${ }^{3,4}$.

In view of this question, the scientific production on LQ and IBD was chosen as the object of research in this review. It was sought to answer the following guiding question: what is the state of the art of scientific production on IBD and QV in journals of international and national circulation? The objective of this study is to identify the scientific production on LQ of patients with IBD in the period from 2012 to 2016. This study is justified by the necessity to highlight the LQ of people with IBD, since it is a chronic condition that requires physical and psychological adaptations.

\section{METHODOLOGY}

This is an integrative review of the literature on the LQ of patients with IBD. Integrative review is a research method that allows the synthesis of relevant studies and allows general conclusions regarding knowledge about a given topic, helping clinical decision making and identifying gaps related to the study area ${ }^{10}$.

The bibliographic survey was realized through the search of scientific articles published in journals and periodicals indexed in the Scientific Electronic Library Online (SciELO) and in the Nursing Database (BDENF). The search was performed using the following descriptors: inflammatory bowel disease and Crohn's disease; inflammatory bowel disease and rectocolitis; inflammatory bowel disease and life quality.

As an inclusion criterion, the free availability of online articles in full, in Portuguese and/or English, published in the last five years and that addressed the subject under study, was used as inclusion criterion. The exclusion criteria used were duplicity of articles and approaches that are not appropriate to the theme.

Two tables were used to present the synthesis of the selected articles: Table 1, composed of code (identified with the letter $\mathrm{A}$ followed by the number related to the order in which its were read), the title, translation of

Table 1. Description of the articles with the descriptors inflammatory bowel disease and associated life quality, from 2012 to 2016.

\begin{tabular}{|c|c|c|c|c|c|c|c|}
\hline Code & Title & Title in Portuguese & Year & Place & Autores & Languade & Method \\
\hline A1 & $\begin{array}{l}\text { Lower levels of vitamin } \\
\text { D correlate with clinical } \\
\text { disease activity and quality } \\
\text { of life in inflammatory } \\
\text { bowel disease }\end{array}$ & $\begin{array}{c}\text { Correlação entre } \\
\text { hipovitaminose D, } \\
\text { atividade clínica da doença } \\
\text { e a qualidade de vida } \\
\text { na doença inflamatória } \\
\text { intestinal (DII) }\end{array}$ & 2015 & Portugal & $\begin{array}{c}\text { Castro } \\
\text { et al. }\end{array}$ & English & Quantitative \\
\hline A2 & $\begin{array}{l}\text { Treatment of anemia and } \\
\text { improvement of quality } \\
\text { of life among patients } \\
\text { with Crohn's disease: } \\
\text { experience using ferric } \\
\text { carboxymaltose }\end{array}$ & $\begin{array}{c}\text { Tratamento da anemia } \\
\text { e melhora da qualidade } \\
\text { de vida em portadores } \\
\text { de doença de Crohn: } \\
\text { experiência com } \\
\text { carboxymaltose férrica }\end{array}$ & 2015 & Brazil & $\begin{array}{c}\text { Sobrado } \\
\text { et al. }\end{array}$ & English & Quantitative \\
\hline A3 & $\begin{array}{l}\text { Disability in inflammatory } \\
\text { bowel disease: translation } \\
\text { to Portuguese and } \\
\text { validation of the } \\
\text { "Inflammatory Bowel } \\
\text { Disease - Disability Score" } \\
\text { (IBD-DS) }\end{array}$ & $\begin{array}{c}\text { Incapacidade na } \\
\text { Intestinal: Tradução para } \\
\text { Português e Validação } \\
\text { do "Inflammatory Bowel } \\
\text { Disease - Disability Score" } \\
\text { (IBD-DS) }\end{array}$ & 2015 & Portugal & $\begin{array}{c}\text { Magalhães } \\
\text { et al. }\end{array}$ & English & Quantitative \\
\hline A4 & $\begin{array}{l}\text { Quality of life in patients } \\
\text { with inflammatory bowel } \\
\text { disease: importance of } \\
\text { clinical, demographic and } \\
\text { psychosocial factors. }\end{array}$ & $\begin{array}{l}\text { Qualidade de vida em } \\
\text { pacientes com doença } \\
\text { inflamatória intestinal: } \\
\text { importância da evolução } \\
\text { clínica, demográfica e } \\
\text { fatores psicossociais }\end{array}$ & 2014 & Portugal & $\begin{array}{c}\text { Magalhães } \\
\text { et al. }\end{array}$ & English & Quantitative \\
\hline
\end{tabular}


Table 2. Description of the articles referring to the objectives, results and conclusions.

\begin{tabular}{|c|c|c|c|c|}
\hline Code & Authors & Subject objective & Results & Conclusion \\
\hline $\mathrm{A} 1$ & $\begin{array}{l}\text { Castro } \\
\text { et al. }{ }^{1}\end{array}$ & $\begin{array}{l}\text { To investigate the } \\
\text { correlation between } \\
\text { serum vitamin D levels, } \\
\text { the clinical activity of } \\
\text { the disease and the life } \\
\text { quality in IBD patients }\end{array}$ & $\begin{array}{l}\text { Patients in clinical remission } \\
\text { had higher levels of vitamin D. } \\
\text { Patients with SIBDQ }<50 \text { had } \\
\text { significantly lower levels of vitamin } \\
\text { D compared to patients with } \\
\text { SIBDQ } \geq 50 \text {. }\end{array}$ & $\begin{array}{l}\text { The clinical activity and life quality of IBD } \\
\text { patients correlated with lower levels of } \\
\text { vitamin D, illustrating a clear necessity for } \\
\text { vitamin D supplementation in IBD patients. }\end{array}$ \\
\hline$A 2$ & $\begin{array}{l}\text { Sobrado } \\
\text { et al. }{ }^{12}\end{array}$ & $\begin{array}{l}\text { To classify the degree } \\
\text { of activity of the CD } \\
\text { measured by means } \\
\text { of tests of the activity } \\
\text { of CD and C-reactive } \\
\text { protein, in relation } \\
\text { to the severity of the } \\
\text { anemia }\end{array}$ & $\begin{array}{l}\text { After administration of } \\
\text { intravenous iron, life quality score } \\
\text { improvement was observed in all } \\
\text { patients (100\%) after } 12 \text { weeks. }\end{array}$ & $\begin{array}{l}\text { The activity index of CD and C-reactive } \\
\text { protein have a good correlation with the } \\
\text { severity of the anemia. The treatment } \\
\text { of anemia in CD patients through ferric } \\
\text { carboxymaltose is safe and corrects } \\
\text { hemoglobin levels and iron stores, with } \\
\text { consequent improvement in life quality. }\end{array}$ \\
\hline A3 & $\begin{array}{l}\text { Magalhães } \\
\text { et al. }{ }^{4}\end{array}$ & $\begin{array}{c}\text { Translate from English } \\
\text { to Portuguese and } \\
\text { validate IBD-DS }\end{array}$ & $\begin{array}{l}\text { There was a strong negative } \\
\text { correlation between IBD- } \\
\text { DS and SIBDQ, with greater } \\
\text { disability in women, patients with } \\
\text { extraintestinal manifestations, } \\
\text { and receiving sickness or disability } \\
\text { pension. }\end{array}$ & $\begin{array}{l}\text { The Portuguese version of the IBD-DS is a } \\
\text { valid and easily applicable questionnaire, } \\
\text { making it a useful tool in the assessment of } \\
\text { IBD deficiency. }\end{array}$ \\
\hline A4 & $\begin{array}{l}\text { Magalhaes } \\
\text { et al. }{ }^{3}\end{array}$ & $\begin{array}{l}\text { To analyze the } \\
\text { relationship } \\
\text { between clinical and } \\
\text { sociodemographic } \\
\text { factors and life quality in } \\
\text { IBD patients. }\end{array}$ & $\begin{array}{c}\text { The IBDQ scores were significantly } \\
\text { lower in women patients, career } \\
\text { achievement and psychological } \\
\text { support. }\end{array}$ & $\begin{array}{l}\text { The decrease in HRLQ was significantly } \\
\text { related to the women, with the personal } \\
\text { perception of the impact of the disease } \\
\text { on success and social relationships } \\
\text { and requiring psychological support or } \\
\text { pharmacological treatment for anxiety or } \\
\text { depression. }\end{array}$ \\
\hline
\end{tabular}

$\mathrm{CD}=$ Crohn's disease; IBD = inflammatory bowel disease; IBDQ- DS = Inflammatory Bowel Disease Questionnaire - Disability Score; IBDQ = Inflammatory Bowel Disease Questionnaire; HRQL = health-related life quality; SIBDQ = Short Questionnaire on Inflammatory Bowel Disease.

the title, year of publication, the place where the study was developed, the authors, the language used and the study method; and Table 2, composed of code, objectives, results and conclusions.

\section{RESULTS AND DISCUSSION}

In the BDENF no articles were found and in the SciELO database eight were found. After partial reading, four articles were selected for this study, whose cataloging data can be observed in Table 1. In the stipulated time cut, no publication was registered in 2012, 2013 and 2016 that addressed the specificity of the topic. Regarding the distribution of countries, three studies were conducted in Portugal and one in Brazil. About the articles, it can be deduce that all were published in the English language.
Regarding the method of the studies, it was observed that all were of a quantitative nature, and three were analyzed by means of Statiscal Package of Social Sciences (SPSS) of different versions, respectively 18.0,21.0 and 20.0, and a statistically analyzed study by Microsoft Excel 2007.

These studies used the Short Inflammatory Bowel Disease Questionnaire (SIBDQ), the Inflammatory Bowel Disease Questionnaire (IBDQ) and the IBDQ - Disability Score (IBD-DS) to perform data collection on LQ. The SIBDQ evaluates 10 points on systemic, emotional and social domains related to the bowel; each question varies from 1 to 7 , resulting in a total score between 10 (low HRLQ) and 70 (high HRLQ) ${ }^{1}$.

The IBDQ contains 32 items composed of four domains: intestinal symptoms, systemic symptoms, social aspect and emotional aspect. Each response can 
range from 1 to 7 , with 1 corresponding to significant impairment and 7 corresponding to no loss of value. The overall IBDQ score is the sum of the answers to each of the questions, with the total score ranging from 32 (very poor HRLQ) to 224 (perfect HRQL) 3

The IBD-DS aims to assess the disabilities caused by IBD. This questionnaire comprises 58 questions grouped into six domains: mobility, self-care, main activities of daily living, mental health, gastrointestinal problems and social impact ${ }^{4}$.

Based on Table 2, in the study by Castro et al. ${ }^{1}, 76$ people participated, most of them women, with CD being the predominant pathology. The questionnaire applied was SIBDQ. As a result, it was found that people with low LQ had significantly lower mean levels of vitamin D. This study reveals that vitamin D deficiency is common in people with IBD, suggesting to be related to individuals who are in clinical activity and which have decreased LQ, thus requiring supplementation of vitamin $\mathrm{D}$, since there are studies that demonstrate that vitamin $\mathrm{E}$ plays an important role in immunomodulation and thus contributes to the treatment, inducing the immune system to act correctly.

According to Marques et al. ${ }^{11}$, vitamin D deficiency is related to several autoimmune diseases, such as diabetes mellitus, multiple sclerosis, IBD, systemic lupus erythematosus and rheumatoid arthritis. The mechanism by which vitamin $\mathrm{D}$ deficiency occurs most often in IBD is probably due to the low intake and malabsorption of vitamin $\mathrm{D}$ and also by reduced sun exposure. Therefore, it is believed that this vitamin prevents the development of autoimmune diseases and can be used in treatment.

Anemia caused by iron deficiency and chronic inflammatory processes was evidenced by Sobrado et al. ${ }^{12}$ as a common manifestation in individuals with $\mathrm{CD}$ and due to this complication, people have their life affected negatively. Thus, the study addressed the treatment of anemia in 10 patients with $\mathrm{CD}$ by means of ferric carboxymaltose and subsequently applied the IBDQ. The authors found that this treatment is safe and corrects hemoglobin and iron levels and, consequently, improved LQ and that 12 weeks after treatment all the individuals showed a significant improvement in all areas of the questionnaire (Table 2).

Vicente, Decimoni and Quero ${ }^{12}$ state that IBD is one of the main causes of anemia of chronic disease, with a prevalence of iron deficiency anemia around $78 \%$. And they agree with Sobrado et al. ${ }^{13}$ on ferric carboxymaltose that the administration of high doses of intravenous iron is safe, simple and uncomplicated.

With these two studies, it was noted that the treatments can improve the LQ of people with IBD and disabilities from IBD, since these treatments aim to attenuate the clinical activity of the disease through vitamin supplementation and the correction of anemia and iron stores, allowing an advance in the management of these patients.

In the third article, Magalhães et al. ${ }^{4}$ worked with SIBDQ and with the translation of the IBD-DS English language into the Portuguese language. In this study, the population was composed of 85 people, 55 patients with CD and 30 with UC; 53 were women, and it was evidenced that LQ in these patients with IBD showed negative correlation with IBD-DS. He also pointed out that the Portuguese version of the IBD-DS questionnaire is valid and easily applicable, allowing assessment of disability in IBD and its impact on the patient's life, as well as evidence that the greater the disability due to IBD, the lower the LQ of individuals (Table 2).

The last article addressed the significant relationship between QL decrease, women and personal perception of the impact of the disease on success and social relationships. In this study, Magalhaes et al. ${ }^{3}$ applied the IBDQ questionnaire and another with sociodemographic questions, and in the composite sample of 150 patients, 92 had CD and 58 UC; the IBDQ scores were significantly lower in women patients who perceived less support from co-workers who required psychological support and in pharmacological treatment for anxiety or depression (Table 2).

As in the study by Santos et al. ${ }^{14}$, females predominated and $\mathrm{CD}$ was diagnosed in a greater number of individuals in relation to $\mathrm{UC}$. However, in relation to $L Q$, the discovery was contrary to that found in Souza et al. ${ }^{2}$, who observed a significant change in LQ in men, smokers and among those with active disease.

It was possible to note limitations in the article by Castro et al. ${ }^{1}$, being relatively small, conferring less statistical power to determine a correlation between vitamin $\mathrm{D}$ and $\mathrm{LQ}$ of the patients. There were no anthropometric measurements (weight, height, body mass index) as well as dietary information that could 
influence the serum vitamin D level. In addition, it was not possible to identify the causality between vitamin $\mathrm{D}$ and chronic gastrointestinal inflammation, whose information could be determined only by means of prospective studies.

Regarding the translation and validation of the questionnaire, Lopes ${ }^{15}$ indicates that a reliable and reproducible study is necessary to demonstrate its validation. Thus, the study by Magalhães et al. ${ }^{4}$ presents limitations when performing the translation and validation of the IBD-DS in parallel relation with the SIBDQ; moreover, when it came to reliability, it was perceived that the study sample was small.

\section{CONCLUSION}

Considering the above, it is possible to notice that women and CD predominate among people with IBD and that LQ is generally negatively affected in these patients, with repercussions on their personal and professional relationships, with a necessity for high psychological support and treatment for anxiety and depression. It was also found that vitamin D and ferric carboxymaltose can improve the LQ of patients with IBD.

The LQ of people with IBD and their sociodemographic aspects are related to low LQ, but in most studies, no sociodemographic aspects are related to low LQ. This identification is important as it can subsidize care guidelines for people with IBD.

In addition, there was a shortage of literature addressing this theme, mainly in studies conducted in Brazil, where only one clinical study was found, considered comprehensive and with significant results, being internationally recognized through seven scientific studies from other countries, in the last two years.

\section{AUTHOR'S CONTRIBUTION}

Conceptualization, Vasconcelos RS and Souza EB; Investigation, Vasconcelos RS and Souza EB; Writing First version, Vasconcelos RS and Souza EB; Writing Second version, Vasconcelos RS; Souza EB and Amaral VRS; Writing - Review \& Edition, Rocha RM and Amaral VRS; Supervision, Rocha RM.

\section{REFERENCES}

1. Castro FD, Magalhães J, Carvalho PB, Moreira MJ, Mota P, Cotter, J. Lower levels of vitamin d correlate with clinical disease activity and quality of life in inflammatory Bowel disease. Arq Gastroenterol. 2015;52(4):260-5. doi: 10.1590/s0004-28032015000400003.

2. Souza MM, Barbosa DA, Espinosa MM, Belasco AGS Qualidade de vida de pacientes portadores de doença inflamatória intestinal. Acta Paul Enferm. 2011;24(4):47984. doi: 10.1590/S0103-21002011000400006.

3. Magalhães J, Castro FD, Carvalho PB, Leite S, Moreira MJ, Cotter J. Quality of life in patients with inflammatory bowel disease: importance of clinical, demographic and psychosocial factors. Arq Gastroenterol. 2014;51(3):192-7. doi: 10.1590/S0004-28032014000300005.

4. Magalhães J, Castro FD, Carvalho PB, Machado JF, Leite S, Moreira MJ, Cotter J. Disability in inflammatory bowel disease: translation to Portuguese and validation of the "Inflammatory Bowel Disease - Disability Score". GE Port J Gastroenterol. 2015;22(1):4-14. doi: 10.1016/j. jpge.2014.10.002.

5. Brasil. Portaria SAS/MS n 966, de 2 de outubro de 2014 Dispõe sobre o Protocolo Clínico e Diretrizes Terapêuticas da Doença de Crohn. Brasília, 2014. Available at: http:// conitec.gov.br/images/Protocolos/DoencaCrohn.pdf.
6. Cruz VA, Yamaguchi L, Ribeiro CN, Magalhães VO, Rego J, Silva NA da. Retocolite ulcerativa e artrite reumatoide: uma rara associação - relato de caso. Rev Bras Reumatol. 2012;52(4):648-50. doi: 10.1590/S048250042012000400014.

7. Cunha RR, Ferreira AB, Backes VMS. Características sócio-demográficas e clínicas de pessoas estomizadas: revisão de literatura. ESTIMA, Braz. J. Enterostomal Ther. 2013;11(2):29-35.

8. Perugini VC, Linhares M, Silva RD da S, Pereira VC, Rocha MS, Collares JV. Processo de viver com estomia: facilidades e limites. ESTIMA, Braz. J. Enterostomal Ther. 2006;4(1).

9. Monteiro SNC, Kamada I, Silva AL. Qualidade de vida: percepção de crianças e adolescentes estomizados e seus pais e/ou responsáveis. ESTIMA, Braz. J. Enterostomal Ther. 2016;14(1):50. doi: 10.5327/Z1806-3144201600010008.

10. Mendes KDS, Silveira RCCP, Galvão CM. Revisão integrativa: método de pesquisa para a incorporação de evidências na saúde e na enfermagem. Texto Contexto Enferm. 2008;17(4):758-64. doi: 10.1590/S0104-0707200800040 0018.

11. Marques CDLA, Dantas AT, Fragoso TS, Duarte ALBP. A importância dos níveis de vitamina $D$ nas doenças autoimunes. Rev Bras Reumatol. 2010;50(1):67-80. doi: 10.1590/S0482-50042010000100007 
12. Vicente AB, Decimoni TC, Quero AA. Análise de custominimização da carboximaltose férrica (e.v.) em comparação com sacarato de ferro (e.v.) no tratamento da anemia ferropriva na perspectiva da saúde suplementar. J Bras Econ Saúde. 2015;7(1):28-37.

13. Sobrado CW, Cançado RD, Sobrado LF, Frugis MO, Sobrado MF. Treatment of anemia and improvement of quality of life among patients with Crohn's disease: experience using ferric carboxymaltose. Arq Gastroenterol. 2015;52(4):2559. doi: 10.1590/S0004-28032015000400002.
14. Santos RM, Carvalho ATP, Silva KS, Sá SPC, Santos AH, Sandinha MR. Inflammatory bowel disease: outpatient treatment profile. Arq Gastroenterol. 2017;54(2):96-100. doi: 10.1590/s0004-2803.201700000-01.

15. Lopes JS. Satisfação dos clientes com os cuidados de enfermagem de reabilitação: contributo para a adaptação e validação do Questionário de Satisfação SNQ-10 [dissertação]. Coimbra (Portugal): Escola Superior de Enfermagem de Coimbra, Mestrado em Enfermagem de Reabilitação; 2012. 